\title{
Fatter Bukh og den primitive Studier i Niels Bukh og hans gymnastik
}

\section{Af Paw Stylsvig Jeppesen}

Der er efterhånden skrevet meget om Niels Bukh og hans gymnastik. Et gennemgående karakteristisk træk for stort set alt det skrevne, er imidlertid at det tilsyneladende er følelser og holdninger, der i højere grad end forsøg på en saglig og nuanceret fremstilling har præget indlæggene. Langt den største del af litteraturen om Bukh, der er skrevet af forskellige repræsentanter fra den nære kreds af medarbejdere og elever fra Ollerup og andre gymnastikfolk er præget af en nærmest ubegrænset loyalitet overfor Bukh og alt det han stod for, gjorde og udtalte sig om $^{1}$. Overfor dette står hans kritikere, der som oftest er mindst lige så unuancerede, hvad enten det gælder kritikken af hans gymnastik eller tolkningen af nogle af hans ofte lidt for bramfrie udtalelser $^{2}$.

Det er hensigten med denne artikel, at bidrage med et lidt mere nuanceret billede af mennesket Niels Bukh og den gymnastik han var eksponent for, og som han stadig idag, for mange, er indbegrebet af.

Den første fase bliver en klarlæggelse af nogle af de idealer Niels Bukh stod for, samt en fremhævelse af hvorledes disse idealer afspejledes i hans gymnastik.

Dernæst vil der ud fra forskellige synsvinkler blive fokuseret på nogle anatomiske og fysiologiske aspekter af gymnastikken.

Der tages udgangspunkt i Bukhs egen kritik af den lingske gymnastik, og argu- mentationen for udviklingen af denne fra stillingsgymnastik til bevægelsesgymnastik. Dernæst vil der med udgangspunkt i en række kritikeres syn på Bukh-gymnastikken blive foretaget en analyse af, hvorledes denne kan virke på legemet.

Endelig skal der redegøres for en række af Bukhs principper, hvad angår den formidlingsmæssige side af gymnastikken. Dels vil Bukhs syn på lederrollen blive diskuteret, og dels skal der redegøres for en række af Bukhs pædagogiske principper, samt for hvorledes gymnastikken anvendtes som opdragelsesmiddel for ungdommen. Kronologisk vil undersøgelsen koncentrere sig om perioden 1912-1950.

I 1912, hvor den svenske gymnastik for længst var blevet altdominerende, havde Niels Bukh allerede virket som gymnastikleder i mange år. Alligevel blev dette år på flere områder skelsættende ikke alene for hans eget videre virke, men også for den samlede gymnastikbevægelse i Danmark.

Ved de olympiske lege i Stockholm dette år havde den finske gymnastikpædagog Elli Bjørkstén givet en opvisning, hvor de kendte Lingske principper blev præsenteret i en ny revolutionerende indpakning. Det revolutionerende bestod $i$, at hun havde gjort gymnastikken til bevægelsesgymnastik.

På et kursus i Silkeborg året efter formidlede hun sine tanker og ideer om den nye gymnastik for en forsamling af de ledende danske gymnastikfolk. Hun ved- 
kendte sig de lingske principper, men mente samtidigt, at gymnastikken måtte udvikle sig i takt med den generelle sociale og kulturelle udvikling i samfundet samt tage udgangspunkt i den nyerhvervede fysiologiske viden. Endelig var hun fortaler for en decideret kvindegymnastik, der skulle rette sig efter æstetiske krav, og den tidligere noget stive stillingsgymnastik skulle afløses af bevægelsesgymnastik (rörelsesgymnastik) ${ }^{3}$. Bukh var meget fascineret af Elli Bjørksteins ideer og nyskabelser, hvilket bl.a. fremgår i en artikel fra 1915, hvori han bl.a. skriver: »Vi skylder frk. Bjørkstén fra Finland stor tak for den berigelse, hun med sin rige, kunstneriske natur har bragt vor gymnastik. Hun har udvidet grænserne for gymnastikundervisning og vist os den inderlige forbindelse, der er imellem legeme og sjæl, en forbindelse, som gør målet for gymnastikundervisning langt større og skønnere at stile imod $\aleph^{4}$.

I de følgende år vandt den bjørksteinske udlægning af den svenske gymnastik mere og mere indpas. Ikke overraskende var det specielt ungdommen, der var fascineret af den nye gymnastik, medens de ældre gymnaster foretrak stillingsgymnastikken, som de var opdraget med. I sidste ende blev det dog alligevel Bjørksteins bevægelsesgymnastik, der definitivt »sejrede«, og den skulle da også komme til at danne skole for den lingske gymnastiks udvikling helt frem til 1950. I den forbindelse kom de to gymnastikhøjskoler i henholdsvis Ollerup og Snoghøj til at stå meget centralt.

Ollerup Gymnastikhøjskole, der blev bygget i 1920, udviklede sig hurtigt til at blive »et kraftcentrum i legemskulturen på landet $\ll^{5}$. Grundlaget herfor var den $»$ primitive gymnastik«, som Niels Bukh havde udarbejdet delvis på baggrund af de bjørksteinske principper.
Bukh-gymnastikken kulminerede i 1930'erne og 1940'erne, hvilket tydeligt kom til udtryk ved landsstævnet i Odense i 1947, hvor et flertal af lederne kom fra Ollerup og Snoghøj og hvor hele 5/6 af de mandlige gymnaster viste Ollerup-gymnastikken. I perioden efter Niels Bukhs død i 1950 måtte Ollerup-folkene dog efterhånden langsomt vige til fordel for andre gymnastikformer, der oftest udvikledes fra byerne, hvorfra de bredte sig, og efterhånden fortrængte den etablerede gymnastik. Langt op i 1960'erne var der dog stadig mange skolebørn og gymnaster, der stadig blev udsat for en gymnastik med rødder tilbage til Bukh, og den dag idag er de helt store diller Jane Fondas »Workout « og »aerobics «, der efter nogles mening nedstammer i lige linie fra den primitive gymnastik ${ }^{6}$.

\section{Idealisten Niels Bukh}

Noget af det første, man erfarer, når man beskæftiger sig med Bukh, er, at han var idealist. Det fremgår med al tydelighed af hans egne artikler og bøger, og i omtalen fra de personer han omgik. Han havde nogle klart definerede mål og værdier. Når han først havde sat sig en ting i hovedet, gik han fuldt ud ind for den, og var umulig at bremse, før end det erklærede mål var nået. Dette var nok en af de væsentlige årsager til, at Bukh præsterede, hvad han gjorde, til stor beundring for den store skare af venner og beundrere, han fik i løbet af årene. Når kursen mod et mål først var stukket, var der ingen vej tilbage. Da Bukh samtidig på ingen måde var kompromisets mand, og oftest udtalte sig temmeligt bramfrit og udiplomatisk i sager, hvor han mødte modstand, måtte han selv sagt også få en række fjender.

Hans erklærede mål med gymnastikken, 
således som det med al tydelighed fremgår af næsten alt, han har skrevet, var at bibringe ungdommen legemskultur og dermed genoprette den gode holdning hos landbrugere og andre, hvis holdning var præget af hårdt ensidigt arbejde. De vigtigste faktorer i forbindelse med den gode holdning var smidighed, muskelstyrke og koordinationsevne. Sidstnævnte kaldte Bukh for behændighedstræning. De ting, der skulle afspejles i den gode holdning, var således sundhed, kraft, harmoni og energi.

I sit arbejde, som på alle andre områder, var han perfektionist. Dette gjaldt især, når det drejede sig om elevernes udførelse af de gymnastiske $\emptyset$ velser. Mads Nielsen skrev i en nekrolog følgende om Bukh: »Som leder af et gymnastikhold var han af et ganske særligt format. Frodig fantasi, megen viljestyrke, et skarpt blik for form og en utrættelig higen efter at nå det fuldkomne, det helt skønne, var bærende i hans undervisning. Med sit stærke temperament reagerede han hårdt mod enhver fejl, der forstyrrede det billede af dygtighed, fuld indsats og skønhed, han ville have frem, undertiden så hårdt, at det slog modet ned på den, det gik ud over... i hans timer har mange lært, at ydeevnens grænse ikke er nået så hurtigt, som de fleste tror «?

Mads Nielsens karakteristik afspejler en meget autoritær leder, hvor det næppe har været særligt fornuftigt at komme med indsigelser i forbindelse med de gymnastiske $\emptyset$ velser. Kristian Krogshede har beskrevet ham som en en strålende underviser og en meget temperamentsfuld mand, "han kunne være lys, så han løftede os fra jorden, og han kunne være mørk, så han kuede os, så vi var grædefærdige mange gange $\ll^{8}$.

Bukh var stor modstander af konkurrence indenfor gymnastikken, hvilket bl.a. kom til udtryk under hans deltagelse i de olympiske lege i Paris i 1924, som han kun indvilligede $i$ at deltage ved, såfremt, det var udenfor konkurrencen 9 . Et andet tydeligt eksempel på hans nedladende holdning til »konkurrenceuvæsenet « fremkom i hans skarpe kritik af skytterne i 1929 op til Dybbølstævnet, hvor han kritiserede disse for kun at dyrke idrætten for præmiernes og placeringernes skyld. Han udtalte bl.a.: »Jeg har ikke noget imod at bønderne ved deres dyrskuer hænger medaljer og diplomer på deres kvæg for derved at fremavle det bedste. Men det er nedværdigende at behandle vor ungdom på samme måde, det virker afsporende og fordummende og dræber den idealisme, der burde være sagen $\ll^{10}$. Det er derfor paradoksalt nok, at det netop var et sportsligt nederlag, der var en af de direkte afgørende faktorer for Bukh til at introducere den primitive gymnastik. Det var under de olympiske lege i Stockholm i 1912, at Bukh på baggrund af nederlaget til svenskerne fandt, at den snæversynethed, som dommerne var underlagt, lukkede alt nyt ude, og at der var behov for en udvikling af den lingske gymnastik ${ }^{11}$.

Et andet meget karakteristisk træk ved Bukh var hans meget nationale sindelag. Man får det indtryk, at hele hans arbejde var tilegnet Kongeriget. Når han rejste med hold i udlandet var det som repræsentanter for Danmark. Han søgte at få sine gymnaster til at fremstå med skønhed, naturlighed og kraft, og Dannebrog havde altid en meget central placering i opvisningen. En af lærerne under Niels Bukh, Rask Nielsen mener, at denne fædrelandskærlighed kom til udtryk i hele hans meget respektfulde omgang med det danske flag, i den måde han omtalte og behandlede det, når han førte det frem i udlandet. Han så gerne, at man fik et indtryk af, at danskerne stod for skønhed, harmoni og evne til samarbejde ${ }^{12}$.

Om det nationale aspekts betydning $\mathrm{i}$ ar- 
bejdet har Bukh selv skrevet i en avisartikel omhandlende hjemkomsten efter en Amerikatur: »Efter denne for os særdeles indholdsrige tid vendte vi pr. damper tilbage til København. Da vi på hele turen havde kæmpet under gamle Dannebrog, faldt det os naturligt, at vi ved ankomsten til København ville samles omkring flaget og synge »Der er et yndigt land «, når båden gled $\mathrm{i}$ havn. Det var ikke, fordi vi ventede nogen særlig modtagelse i kongens by, men udelukkende dikteret af en trang til at bekende vort nationale sindelag $\ll^{13}$.

På en tysklandsturne i 1924 mødte han dog nogle protester mod det stærkt nationale islæt som opvisningerne havde, i kraft af Dannebrogs centrale placering og de nationale sange ved ind- og udmarch. Dette lod Bukh sig dog ikke anfægte af, og han fik overalt trumfet sin vilje igennem og fik fanen med under opvisningerne ${ }^{14}$.

Under jordomrejsen i 1931 havde han fra Udenrigsministeriet, i forbindelse med nogle opvisninger i Sovjetunionen, fået en orientering om, at $\gg$ det ikke var skik og brug i Rusland, at der ved idrætsopvisninger eller lignende blev båret nationalt flag eller sunget nationale sange «, og man henstillede til Bukh om at tage hensyn til dette. Det samme gjorde de russiske værter, men Bukh hverken ville eller kunne optræde uden Dannebrogs centrale placering, og således blev det. Han var tilsyneladende fuldstændig kompromisløs, når det angik fanen, idet han slog på vigtigheden i denne markedsførelse af danskheden og dansk kultur. ${ }^{15}$

Det var stort set de samme idealer, som Bukh havde, der var gældende syd for grænsen i 1930'erne. Bukh udtalte sig da også ved flere lejligheder positivt overfor de resultater Hitler havde nået med Det Tredie Rige ${ }^{16}$. Dette bevirkede naturligvis, at Bukh og dermed det, han var indbegrebet af, nemlig gymnastikhøjskolen og den primitive gymnastik, kom i kraftig miskredit.

De mennesker Bukh havde fået kontakt med i Tyskland i 1920'erne havde siden sã godt som alle sluttet op bag Hitler. Det var alle sammen mennesker Bukh i kraft af sit personlige kendskab havde tillid til, og i mange tilfælde idealister som han selv. Dette sammenholdt med Hitlers egenskaber, som manden, der formåede at samle folket, give det handlekraft og tro på fremtiden, var for Bukh så stærke personlige egenskaber, at han ikke betænkte sig på at rejse på turne i Tyskland, Ungarn og Østrig i efteråret 1933. Han blev da også modtaget med åbne arme af de nationalsocialistiske værter og det tyske publikum. De meget positive oplevelser fra opvisningerne sammenholdt med det noget unuancerede glansbillede af det nye Tyskland, som værterne forsøgte at vise Bukh, fik denne til at udtrykke sin sympati for systemet. I en artikel i Berlingske Tidende udtalte han: »Det er rigtigt, at jeg har sagt til arrangørerne i Berlin, at jeg, hvis jeg var tyve år yngre, gerne ville tage den opgave op, som Hitler har løst i Tyskland. Vi trænger til at få orden i sagerne, vi har vænnet os til at have det for godt herhjemme. Jeg synes, vi i høj grad trænger til en mand med stærke og rene idealer i stedet for den kolde og golde statsform, vi har i øjeblikket. Og jeg forstår ikke den mistænkeliggørelse, der i udlandet rettes mod Hitler. Jeg har selv både set og hørt, hvorledes jøderne i fred of ro kan passe deres forretninger. Hitler gør dem ikke noget, bare de vil arbejde. Men han vil drive dem ud af spekulation og administration, - med andre ord, han vil hindre dem $\mathrm{i}$ at udnytte de produktive arbejdere. Der er ingen falskhed $i$ ham, og ingen presse skal nogensinde mere rokke min tro på ham $\ll^{17}$.

Naive udtalelser som disse bevirkede selvfølgelig, at Bukh snart blev stemplet 
som nazist. Rask Nielsen, der rejste sammen med ham i perioden, mener dog ikke at Bukh på nogen som helst måde havde politiske ambitioner eller en særlig forkærlighed for det nationalsocialistiske partis politiske program. Han mener, at Bukh blot blev imponeret over et samfund med mange af de samme idealer, som han selv havde, og som, det i lighed med, hvad han selv havde oplevet, var blevet mødt med megen modvilje og kritik fra det eksisterende systems side ${ }^{18}$.

Efter De olympiske Lege i 1936 var han stadig meget begejstret for det nationalsocialistiske Tyskland. I årsskriftet skrev han bl.a.: »Jeg var meget glad ved mit besøg i Berlin og Nürnberg og de $\emptyset$ vrige steder, hvor min rejse gik hen, og jeg mener stadig - uden i mindste måde at være nazist - at vi godt af det nye Tysklands dygtighed, sammenhold og offervilje overfor alt, hvad tysk er, kan styrke vore bestræbelser på at få de tilsvarende gode evner og egenskaber til at vokse yderligere herhjemme - naturligvis af dansk grund, i dansk ånd og med danske mål for $\varnothing j \mathrm{j} \ll^{19}$.

Denne sympatitilkendegivelse for det tyske, som Bukh i flere tilfælde fastholdt under besættelsen, gjorde ham selvsagt til et let offer for de personer, der $\varnothing$ nskede Bukh stillet $i$ et dårligt lys. Rask Nielsen nævner i den forbindelse en episode i Fåborg i 1940, hvor Bukh under en gennemmarch med et pigehold dels passerer nogle danske og dels nogle tyske soldater. De danske soldater tog ingen notits af fanen, og »viste nærmest en flabet opførsel«, medens de tyske soldater indtog stram honnørstilling, da pigerne defilerede forbi. Senere på dagen holdt Bukh en tordentale til gymnasterne, hvor han ikke undlod at tilkendegive sin holdning til de danske soldaters ringeagtende attitude i forbindelse med gymnasternes march, samtidig med, at han fremhævede tyskernes respekt for fanen som det gode eksempel ${ }^{20}$.
Arne Mortensen, der var lærer under Bukh, mener at Bukhs fascination af Hitler skyldtes de oplevelser Bukh havde under sine besøg i 1920'erne i Weimarrepublikken. Da oplevede han depressionen med massearbejdsløshed, demonstrationer, og hvad han selv kaldte kaos, som influerede på holdets rejser m.h.t. forsinkede togáfgange og anden uorden. Desuden var det under Weimarrepublikken, at han havde oplevet, at man ville forbyde brug af fanen ved opvisningerne. Med Hitlers magtovertagelse oplevede han forskellen, og var meget fascineret af den orden, der blev herefter. Han mente, at Hitler blandt andet med afskaffelse af arbejdsløheden gav de unge mennesker håb for fremtiden ${ }^{21}$.

Biskop Dons Christensen, der kendte Bukh gennem de sidste år, mente, at Bukh, som det også med al tydelighed fremgår af ovenstående, i politisk henseende var »fuldstændig naiv«, og han mener, at Bukhs holdninger i stedet gik på, at alt hvad der kunne fremme ungdommens kår dels i Danmark og dels ude i verden, det var sager Bukh kunne gå ind for ${ }^{22}$.

Fascinationen af det nye Tyskland, har ganske afgjort været til stede hos Bukh. Der er dog langt fra det samme, som at stemple ham som nazist. Principperne om en stærk og handlekraftig leder, samt fremhævelsen af det nationale sammenhold fremfor klassemodsætningerne har afgjort appelleret til Bukh. Derimod er der intet belæg for, at Bukh skulle være enig i den tyske racelære, aggressionerne overfor nabolandene eller andet af det, som nazismen stod for. I det hele taget var det en tid, hvor totalitarismen havde gode kår i Europa, og hvor mange så en stærk leder som den eneste mulighed ud af den $\varnothing$ konomiske depression, som var startet med børskrakket i 1929. Disse forhold må man have med i si- 
ne betragtninger, og i det hele taget vurdere folks handlinger ud fra den tid, de levede i, førend man fælder sin dom, og stempler dem.

\section{Den primitive gymnastik}

Såvel personen Bukh, som hans gymnastik var på mange måder kontroversiel. Den gymnastik han introducerede, var da også et afgørende brud med den gymnastik, man var vant til. I lighed med alt andet nyt, der vinder frem, mødte den selvsagt kritik fra de mest konservative af gymnastikfolkene, der satte en ære i at forsvare alt eksisterende og forkaste al nytænkning inden for deres felt. Men også mere saglig og videnskabelig dokumenteret kritik blev den primitive gymnastik udsat for.

I det følgende skal der først redegøres for Bukhs egen kritik af den gamle lingske gymnastik samt hans motivering for udviklingen af den primitive gymnastik. Dernæst skal der foretages en analyse af Bukh-gymnastikken, og der skal redegøres for den kritik, som gymnastikken mødte. Bukhs erklærede mål med gymnastikken var, at den skulle virke som kompensation mod erhvervsarbejdets negative indvirkning på kroppens holdning og udseende.

Især det hårde landbrugsarbejde førte til misdannelser og nedslidninger, og hans filosofi gik ud på, at kun såfremt man kunne iværksætte nogle gymnastiske $\emptyset$ velser, der modvirkede dette, kunne man genoprette kroppens harmoni ${ }^{23}$.

Han mente ikke, at den traditionelle svenske gymnastik hertil var effektiv og rationel nok, idet Lings arvtagere »havde spændt hans ide ind i et gymnastisk system, der hindrede ideens fulde udfoldelse $\ll^{24}$. De havde indskrænket sig til kun at anvende »en bestemt og nøje afgrænset $\varnothing$ velsesræk- ke, som de eneste brugelige midler i systemet, og man tillagde disse øvelser en sådan ufejlbarlighed, at da de viste sig ude af stand til nogenlunde hurtigt og sikkert at føre frem mod det rigtige mål, så ændrede man hellere dette end gav frihed i valg og brug af midler $\aleph^{25}$.

Han mente ikke, gymnasterne skulle lære en række $\emptyset$ velser alene for systemets skyld. Derimod skulle målet være et arbejde for menneskers skyld. Det ville med andre ord sige, at arbejdet skulle tage udgangspunkt i de områder, hvor »vanrøgt og misbrug « havde sat sine spor. Meningen med gymnastikken skulle ikke være at lære gymnasterne en række øvelser, men derimod at anvise og vejlede i brugen af nogle arbejdsbevægelser, der kunne modvirke og befri gymnasterne for de erhvervede holdningsfej $1{ }^{26}$. Han tog med andre ord udgangspunkt $i$, at gymnasterne var »syge «, $o g$ at den rette medicin i den forbindelse var gymnastikken.

Smidighedsøvelser var efter Bukhs mening de mest påkrævede, idet han fandt, at den største hindring for en fri og uhindret bevægelse var den arbejdende ungdoms stivhed. Denne type $\varnothing$ velser blev derfor de første Bukh begyndte at udarbejde. I næste række kom udarbejdelsen af øvelser til forøgelse af muskelstyrke og behændighed (koordination), således at det samlede mål blev en kombination af en fjernelse af erhvervet stivhed, samt en optræning af forsømte muskelgrupper og en afhjælpning af »det kejtede og vanebundne hos ungdommen $\ll^{27}$.

Bukh erfarede dog, at der måtte mere til end blot almindelig gymnastik, som den hidtil havde været praktiseret, såfremt man skulle opnå de erklærede mål. De smidiggørende $\varnothing$ velser måtte gøres langt større og mere dybtgående, og hvad angik muskelstyrketræningen, så fordrede den større 
og større belastninger fra dag til dag, såfremt den skulle have en effekt. Endelig måtte der også stilles langt større krav til koordinationen i de daglige $\emptyset$ velser, såfremt disse skulle forbedres. Resultatet blev en gymnastik, der afløste det hidtil kendte svenske system, med dets bundne bevægelser og stillinger, og som ifølge $\mathrm{Bu}-$ kh selv »viste sig, at fjerne ånde- og hjertebesværligheder og gøre det muligt at gennemføre gymnastiktimernes talrige sving og kraftige vridninger, strækninger og bøjninger uden overanstrengelse $\ll^{28}$.

Med hensyn til Lings børnegymnastik, så accepterede Bukh dog, at den var blevet tilført lidt leg og motion, dog fandt han det beklageligt, at det holdningsgivende moment ikke blev vægtet stærkt nok ${ }^{29}$. Under et børneidrætsstævne i 1934 afholdt på Gymnastikhøjskolen, men med deltagelse af elever fra de højere skoler fra hele landet, fandt han dette meget udtalt. Børnene var selv sagt ikke ledet af Bukh-folk, men i stedet af seminarieuddannede lærere og lærere fra Statens Gymnastikinstitut. Han mente slet ikke, der var fart nok på gymnastikken, lærerne var alt for forsigtige og usikre på øvelsernes gennemførelse, »og man påtvinges den nedslående opfattelse, at det kan være lærerne, der virker hindrende på skolegymnastikken«. Bukh mente, det var nødvendigt for børnene »at puste og svede og anstrenge sig hårdere og hårdere fra dag til dag «, og at læreren i hvert fald ikke skulle være den, der var med til at bremse farten ${ }^{30}$.

Langt værre var det imidlertid, at man i foreningerne lod gymnastikken blive konkurrencebetonet, hvilket Bukh fandt aldeles uheldigt, da selveste ideen med gymnastikken, netop skulle være et værn imod dette. Han mente, at konkurrencegymnastik og rekordsport gjorde midlet til mål og menne- sket til maskine, og havde som sådan intet med legemlig opdragelse at gøre ${ }^{31}$.

Bukh var også af den opfattelse, at man generelt i blandt ungdommen fors $ø$ mte legems $\varnothing$ velser til fordel for den skolemæssige og faglige uddannelse. Dette misforhold mellem den åndelige og fysiske udvikling $\mathrm{i}$ ungdommen, mente Bukh også fik konsekvenser i form af mangel på »legemlig skønhed, sundhed og duelighed.« Det var imidlertid Bukhs egne erfaringer med den svenske gymnastik, der fik ham til for alvor at stille spørgsmålstegn ved dens effekt. Han mente, der måtte være noget galt, når han stadig i april kunne mærke novemberstivheden, og når hans udholdenhed var dårligere $\mathrm{i}$ foråret efter vinterens gymnastik, end til efteråret når boldspillet sluttede $^{32}$. Denne holdning forstærkedes selv sagt af, at han i forbindelse med udtagelsen til olympiaden i London i 1908 blev vraget, fordi han var for stiv.

Konsekvensen af disse iagttagelser og erfaringer, sammenholdt med inspirationen fra Elli Bjørkstein, var de egentlige baggrunde for Bukh til at udvikle og introducere den primitive gymnastik.

Ideerne til den primitive gymnastik fik han i høj grad under sin uddannelse til sygegymnastikinstruktør. Han fandt at sygegymnastikken var langt mere målrettet end den lingske gymnastik. »Her tog vi ofte hårdt fat såvel med aktive som med passive strækninger og bøjninger, og hvor patientens egne kræfter ikke slog til, der satte vi vore ind $\ll^{33}$.

Bukh mente at problemet med den manglende effekt primært skyldtes, at $\emptyset v e l-$ serne generelt ikke blev udført hurtigt nok. Konsekvensen blev naturligt nok, at han lod øvelserne udføre i et meget højt og hidtil uhørt tempo, hvilket da også blev det mest karakteristiske træk i hans arbejdsmetode $^{34}$. 
Bukh's metode førte til en kraftig kritik fra forskellige sider, blandt andet fra lægekredse, der mente hans gymnastik var mere misdannende end just dannende ${ }^{35}$.

Kritikken syntes dog ikke at have påvirket Bukh synderligt. Han mente snarere, at den var forudsigelig, idet der var tale om en meget markant ændring $\mathrm{i}$ forhold til de tidligere meget stillestående øvelser og stillinger. Han virkede imidlertid slet ikke i tvivl, når det angik hans egne metoder. De havde, i modsætning til den gamle gymnastik, vist sig effektive, hvad angår den »holdningsmæssige værdi $\ll$.

Dette med holdningen var tilsyneladende altafgørende for Bukh. Man kunne i princippet foretage sig hvad som helst, bare det havde en positiv virkning på holdningen. Eksempelvis måtte børnegymnastikken gerne være præget af lege, når blot »interessen for virkningsfulde bevægelser til opretholdelse eller forbedring af holdningen stadig præger udførelsen $\ll^{36}$.

Han mente egentlig godt, at de frie idrætter alene uden hjælp af gymnastikken, kunne sikre en tilfredsstillende legemsdannelse, hvis man blot udnyttede dem alsidigt, hvilket ville sige en kombination af atletik, boldspil og svømning ${ }^{37}$.

Gymnastikken tog udgangspunkt i de fritstående øvelser, hvor der arbejdedes med koordination, bevægelighed og styrke for de forskellige muskelgrupper. Målet var hele tiden at rette op på den dårlige holdning, og udbedre de holdningsfejl, som Bukh blandt andet kaldte »buehals«, »rundryg«, »svajryg«, »krogede knæe« samt manglende herredømme ${ }^{38}$. Disse skavanker skyldtes forskellige forhold, så som for korte muskler, disharmoni i styrkeforhold mellem antagonister samt for svagt udviklede muskler. De fleste af disse skavanker var opstået på grund af personens tunge og ensidige fysiske arbejde.
Bukh forklarede, at når der opstår unaturlige krumninger på hvirvelsøjlen som konsekvens af længere tids ensidig belastning, sker der langsomt en gradvis deformering af såvel de enkelte led i hvirvelsøjlen, samt i de mellemliggende disci. Denne deformering er som regel en kileformning af led eller discus og bevirker en indskrænkning $\mathrm{i}$ bevægelsesfriheden. Problemet opstår ved at krumningerne i hvirvelsøjlen bliver for store $\mathrm{i}$ forhold til den naturlige krumning, og forstærkes af et uhensigtsmæssigt skævt styrkeforhold i muskelgrupperne omkring leddet ${ }^{39}$. Konsekvensen i sidste ende bliver en begrænsning i bevægelsesfriheden $i$ hvirvels $\varnothing j l e n$. Denne stivhed kan fjernes med den rette primitive gymnastik, på samme måde som man kan styrke halsmuskulatur, rygstrækkere samt mavemusklerne, hvilket tilsammen giver de optimale betingelser for en god højdeholdning.

I Bukh's terminologi var der flere forskellige sider af holdningen, nemlig dels højdeholdning, som er analog med hvirvelsøjlens forl $\varnothing b$, og dels tværholdningen, som handler om skuldres og brystkasses placering, hvor de centrale muskelgrupper er hættemusklen (m.trapezius), rombemusklen (m.rhomboideus), deltamusklens bagerste del (m.deltoideus), samt den lille trinde muskel (m.teres major). Disse muskelgrupper, der alle blandt andet har som funktion at føre skuldrebladene sammen, og dermed virke til en fremskydning af brystkassen, skal alle styrkes med henblik på en bedre holdning. Samtidig skal brystmuskulaturen udspændes, da hvilelængden af disse muskler normalt er for kort, hvilket giver problemer i forbindelse med armenes og skuldrenes bevægelsesfrihed i specielt de høje stillinger.

Mavemuskulaturen har som allerede omtalt en rolle for højdeholdningen, men samtidig har den også en beskyttende funktion 
for de indre organer, som ligger bag. Desuden mente Bukh, at veltrænede mavemuskler kan give de bagvedliggende organer en form for massage, som kan fremme både blodcirkulation og stofskifte. Endelig var Bukh af den opfattelse, at det er væsentligt at optræne strækkemusklerne over de forskellige $1 \mathrm{ed}^{40}$, idet det typisk i det daglige arbejde er bøjemuskulaturen der er i anvendelse. Samtidig med en generel styrketræning i strækkemusklerne, mente Bukh, at det er væsentligt med udspænding af hasemuskulaturen $^{41}$. For korte hasemuskler bevirker ganske vist, at den rette bækkenholdning bibeholdes, men dette er ikke særligt gunstigt, da det hindrer benenes optimale bevægelsesfrihed. Derimod skal den rette bækkenholdning opretholdes af en stærk mavemuskulatur.

Endelig påpegede Bukh nødvendigheden af at arbejde med koordinations $\emptyset$ velser. Dette gøres bedst ved at kræve den bedst mulige form overholdt $i$ alle $\varnothing$ velsernes udførelse. Herved optrænes de fine samspil mellem nerver og muskler, og de kejtede bevægelser skulle herved gerne forvandles til en æstetisk nydelse.

Et af Bukh's væsentligste kritikpunkter mod den gamle gymnastik var den manglende aktivitet. Der måtte normalt ikke foretages nogen former for bevægelse, hvis ikke den først var udkommanderet. Øvelserne tog udgangspunkt i retstilling og skulle også afsluttes således, før end man kunne gå i gang med næste $\varnothing v e l s e$. Dette sammenholdt med at der krævedes samtidighed i udførelsen af $\varnothing$ velserne, medførte at den lange strøm af kommandoråb, som var en forudsætning for denne form for ledelse, bevirkede mange små pauser mellem de enkelte $\varnothing$ velser. Bukh ændrede dette ved at udelade alle de overflødige kommandoer, og ved at vejlede og kommentere den enkelte gym- nasts udførelse af $\varnothing$ velserne medens $\varnothing$ velserne var igang. Han sørgede også for at instruere i den næstfølgende $\varnothing$ velse medens gymnasterne var aktive, hvilket selvsagt har betydet en stor reduktion i pauserne ${ }^{42}$.

Hvergang der startede et nyt elevhold på gymnastikhøjskolen, blev fysikken undersøgt og svaghederne afsløret i alle elevers påsyn. Stivhed og styrke måltes ved forskellige tests. Eksempelvis blev stivheden $\mathrm{i}$ skulder og brystregion målt $\mathrm{i}$ en »aktiv spændbøjning «, medens stivheden i lænd, hofte, hasemuskler og adduktorer blev klarlagt i tilsvarende $\varnothing$ velser. Mavemuskulaturens styrke måltes $\mathrm{i} \gg$ hængende benføring til bukhæng « i ribben og i »knæstående kropbøjning bagud til gulvet«. Ved hjælp af øvelserne kunne man afsløre svaghederne, og havde hermed en baggrund for graden af den enkelte elevs smidighed. Testen dannede udgangspunkt for en inddeling i tre hold, nemlig det stive, det halvstive og det smidige hold ${ }^{43}$.

Han anviste en lang række forskellige $\emptyset$ velser til udbedring af de ovennævinte »skader«, hvor i blandt nogle var parøvelser, og hvor gymnasterne på skift fik foretaget passive udstrækninger af muskelgrupperne. Disse $\emptyset$ velser er senere blevet kraftigt kritiseret p.g.a. risikoen for overrivning eller forstrækning af ligamenter, og anvendes idag overhovedet ikke af samme grund (herom senere).

I princippet var Bukh af den opfattelse, at der ikke skulle være forskel på gymnastikken for mænd og kvinder. Lederen burde dog tage hensyn til kønnet i sine valg af udgangsstillinger og $\varnothing$ velser, samt i sine krav om kraftudfoldelse; men da alle, uafhængigt af køn, har et skelet, hvori knoglerne er forbundet med hinanden på samme måde, og alle besidder den samme slags muskler fæstnet til de samme steder på 
knoglerne, ligesom menneskenes nervesystem i almindelighed svarer til hinanden i bygning og virkemåde, mente Bukh, at gymnastikken generelt burde tilrettelægges ens for alle. Det er jo i skelettet, i muskulaturen og i nervevirksomheden, at henholdsvis »det stive, kraftløsheden og det kejtede gør sig gældende såvel hos kvinder som hos mænd, så kan gymnastik også i det væsentlige tilrettelægges ens for alle $\ll^{44}$.

Bukh var stor modstander af de ledere, der prøvede at videreudvikle hans primitive gymnastik. Han mente, at det var vigtigt, at værne om gymnastikken, således som den tog sig ud i sin oprindelige form, da han selv lancerede den. Hans kritik gik først og fremmest på, at »forvanskningen « af den primitive gymnastik, kunne resultere $i$, at gymnastikken mistede noget af sin kraft og virkning, i og med at den blev blandet med fremmedelementer. På samme måde mente han heller ikke, at de nye gymnastikformer, der importeredes fra andre lande, havde nogen berettigelse i Danmark. Han mente, at den importerede gymnastik var udformet til brug for »damerne fra byerne og til de studerende kredse, der dyrker gymnastik «, hvorimod Danmark har en »bondeungdom så oplyst og intelligent, at det her er den, der i størst tal samles om frivillig gymnastik i foreningerne. Men hvad den ungdom først og fremmest trænger til, er primitiv gymnastik $\ll^{45}$.

\section{Kritikken af den primitive gymnastik}

Bukh havde dog langt fra opbakning til sin gymnastik fra alle sider. En af Bukh's skrappeste kritikere var professor Lindhard, der i sit gymnastikteoretiske værk karakteriserede primitiv gymnastik, som »en besynderlig blanding af nationalisme, højtra- vende etik og hjemmelavet hygiejne med brudstykker af en mindre velfunderet gymnastikteori $\ll^{46}$. Han mente ikke, der var tale om en udvikling af et nyt gymnastiksystem, men snarere en ny undervisningsmetode, hvilket Bukh iøvrigt ikke var uenig i. Øvelsestyperne var næsten alle hentet fra Ling. Det nye i metoden var anvendelsen af hjælpere, hvor man ikke nøjedes med at påvirke legemet med egne muskler, men lod en eller flere andre tage fat for at mobilisere elevernes led. Lindhards kritik gik primært på det maskuline i gymnastikken. »Det hele antager ofte en så voldsom karakter, at selv veltrænede mænd kan have ondt ved at følge med..... med kvindegymnastik, derimod, har disse $\emptyset v e l s e r$ intet at skaffe $\ll^{47}$.

Bukh har i sin bog præsenteret nogle deciderede kvindeøvelser, som Lindhard dog finder højest upassende, da halvdelen tager udgangspunkt i bredstående stilling, »vel nok den mest maskuline og den mindst kvindelige af samtlige gymnastiske udgangsstillinger «. Desuden er han meget fortørnet over, at der ikke i bogen er illustrationer med kvindelige gymnaster, hvilket Bukh dog har kompenseret for i de senere udgaver af bogen, hvor op til halvdelen af illustrationerne viser kvindelige gymnaster.

Lindhard mener, at den primitive gymnastik grundet sine hårdhændede metoder kun delvis vil kunne vinde indpas i den frivillige gymnastik. Som kvindegymnastik eller børnegymnastik er den efter Lindhards overbevisning, dog ganske ubrugelig. Han mener det er ganske uforsvarligt at anvende de passive udspændingsøvelser overfor børn, på grund af den indbyggede skadesrisiko i disse $\varnothing$ velser ${ }^{48}$.

Lindhard har også kritiseret Bukh's idealer omkring det holdningsmæssige. Han finder, at mange af billederne i bogen forestillende mandlige gymnaster med den oppustede brystkasse, udtrykker en tilsidesæt- 
telse af æstetiske hensyn »i en sådan grad, at det nærmer sig det uappetitlige, også på dette område er der planløshed og usikkerhed $\ll{ }^{49}$. Den oppustede brystkasse var ellers netop et af varemærkerne for den rette $h \varnothing j-$ de- og tværholdning, som Bukh stræbte efter med den primitive gymnastik.

Professor, dr.med. Ove Bøje mente, at Bukh i mange tilfælde er gået for vidt, specielt hvad angår den smidiggørende gymnastik. Det er især de passive udspændings$\emptyset$ velser, hvor gymnasterne parvis har bearbejdet hinandens rygsø $\varnothing \mathrm{jler}$, som Bøje henviser til ${ }^{50}$. Han mener, at denne voldsomme smidiggørelse af rygsøjlen, hvor muskler, ligamenter og led er udsat for meget store påvirkninger, kan være årsag til, at der opstår smertefulde lidelser i ryggen. Risikoen ved en overudspænding af hvirvelsøjlens led kan medføre, at ligamenterne ${ }^{51}$ forstrækkes, og dermed virker mindre stabiliserende på rygsøjlen.

Endvidere kan den overdrevne udspænding, der forøger leddenes bevægelighed til det ekstreme, medføre irritation af ledrande og torntappe, når et led i en udspænding kommer i direkte berøring med naboleddet.

Bøje påpeger da også, at han ofte, hos kvinder, der øver sig i at gå i bro, har konstateret Baastrups sygdom, som er en sygdom, der netop er forårsaget af at torntappene gnider mod hinanden ${ }^{52}$. Desuden mener Bøje heller ikke, at man kan se bort fra, at den kraftige smidiggørelse af rygsøjlen kan være en medvirkende årsag til, at der opstår en discusprolaps, f.eks i den lombale del af hvirvelsøjlen, som er meget smertefuld og måske bedre kendt under navnet ischias $^{53}$.

En anden skarp kritiker af de passive udspændingsøvelser var lærer Ottar fra Statens Gymnastikinstitut. Han mente for såvidt godt, at de kunne anvendes af forstandige voksne, der havde fået den fornødne instruktion, men »hvis 18 drenge står i strækbredvinkelhængende håndst $ø$ ttet stilling ved ribberne, og de andre 18 bliver placeret siddende på skulderbladene af $\emptyset$ velsestagerne, og oven i købet får at vide, at det gælder om at bevæge sig op og ned for at få partnerens ryg rettet ud, så kan $\varnothing$ velsen, hvis partneren er stærk, være uden virkning, men er det en svag dreng, kan det tangere mishandling $\ll^{54}$.

Der er ingen tvivl om, at kritikerne har ret i deres påstande om det uheldige i de passive udspændinger, hvorfor man da også fuldstændig er gået væk fra denne type øvelser i dag. Dette skyldes ud over skadesrisikoen, at denne type udspændingsøvelser er uhensigtsmæssige. Forklaringen på dette er, at der parallelt med muskelfibrene sidder nogle nerveceller, kaldet muskeltener. Disse beskytter musklerne mod uventede hårde udspændinger af musklen. Det vil med andre ord sige, at hvis man som i Bukh's smidiggørende $\varnothing$ velser, foretager udspændinger, hvor det er en makker, der sørger for de kraftige, rykvise strækninger af musklen, så vil muskeltenerne blive aktiveret, og musklen vil kontrahere. Man opnår derfor ikke den ønskede udspænding af musklen. Derimod må man foretage udstrækningen langsomt, så strækkerefleksen (muskeltenen) ikke udløses.

Men bortset fra denne type øvelser er det imidlertid svært at afgøre, hvorvidt Bøje og Ottar og andre kritikere i øvrigt har ret, med hensyn til i hvor høj grad gymnastikken er skadelig. Det afhænger jo i sidste ende af, hvorledes man bredt definerer gymnastik- og idrætsskader. Der er jo ikke nødvendigvis tale om, at gymnastikken er årsag til en skades opståen, bare fordi den opstår i en gymnastiklektion. Derimod kan 

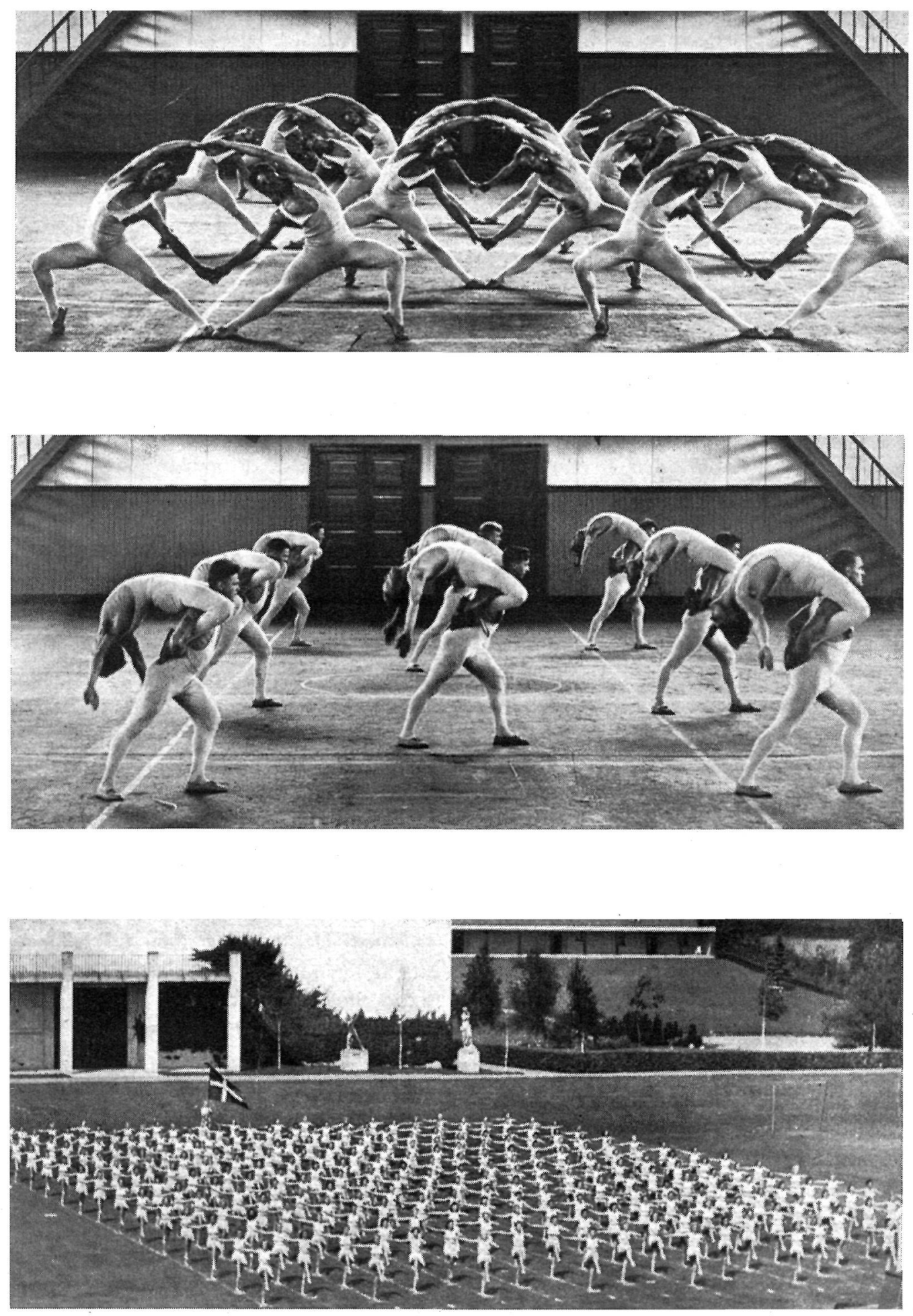
der godt være tale om en person, som gennem længere tids stillesiddende arbejde, har belastet den fibrøse ring (anulus fibrosa) i discus så meget, at den uundgåelige skade mere eller mindre tilfældigt opstår i gymnastiklektionen. I denne konkrete situation kan det måske være meget relevant at diskutere, om skaden skyldes en udspænding i gymnastikken eller den skyldes den langvarige belastning i forbindelse med erhvervsarbejdet.

Det vil dog i realiteten nok være meget vanskeligt præcist at få et billede af eventuelle skadesvirkninger fra gymnastikken, da det ville kræve en undersøgelse af en gruppe gamle gymnaster, der gennem en vis periode har dyrket Bukh-gymnastikken. Skadesfrekvensen for denne gruppe skulle så sammenholdes med en kontrolgruppe. For at kunne dokumentere en eventuelt skadesvirkning kræver det imidlertid, at de to grupper på alle $\varnothing$ vrige områder skulle være ens.

Niels Bukh tog tilsyneladende ikke særlig notits af den samtidige kritik, der rejste sig mod hans nye gymnastikform. Han var så sikker på sin sag, og mente oprigtigt at det var på tide, at der blev sat ind med en virkningsfuld gymnastik, da der alt for længe var brugt tid til »uvæsentlige pillerier«. Kritikken var først og fremmest rettet mod tempoet og den store kraftudfoldelse, som i forhold til den tidligere brugte »exercitsmæssige stillingsgymnastik « var meget revolutionerende på området. At kritikken typisk kom fra de ældre tilhængere af Linggymnastikken, som var vokset op med denne form, samt fra den type ledere, der altid irriteredes af alt nyt, der vinder frem indenfor deres fagområde, overraskede ham ikke, det var vel nærmest, hvad der kunne forventes ${ }^{55}$.

I det hele taget er diskussionen i littera- turen om Bukh's gymnastik generelt i højere grad præget af følelser og holdninger end af saglighed. Dette er da også baggrunden for det meget unuancerede billede, man umiddelbart får af Bukh og hans gymnastik. Enten er Bukh en enestående leder, der har formået at skabe en tiltrængt revolution på gymnastikkens område med en gymnastik, der endelig formåede at fjerne ungdommens stivhed, eller også er han manden med de tvivlsomme politiske holdninger, samt en gymnastik, der var mere misdannende end just dannende. Der er altså på mange måder brug for et mere nuanceret billede af Bukh og det arbejde han foretog.

\section{Gymnastiklederen Niels Bukh}

Bukh's evner som leder er af mange beskrevet som unikke. Han havde sine egne metoder, og han havde en række klare holdninger til, hvorledes man burde være som gymnastikleder. Et af hans kraftigste angreb på den gamle lingske gymnastik gik på, at man dyrkede gymnastikken for $\emptyset v e l-$ sernes skyld, medens Bukh afgjort mente, at gymnastikken skulle tage udgangspunkt i mennesket. I dette sidste afsnit skal der redegøres for, hvorledes Bukh anvendte gymnastikken som opdragelsesmiddel, samt hvorledes han mente den rette gymnastikleder burde udøve sit hverv.

Som opdragelsesmiddel havde opvisningerne en afgørende funktion. Bukh mente, at opvisningerne havde store værdier at byde på. Det var her, man overfor omverdenen demonstrerede, hvor langt man var nået i retning af »harmonisk udvikling og legemsbeherskelse«, og hvor den enkelte skulle demonstrere »ordenssans, skønhedsglæde og ansvarsfølelse« overfor helheden. Opvisningen i sig selv var måske ikke så afgørende, derimod var der i hele trænings- 
arbejdet frem til opvisningen en udvikling af de ovenstående kvaliteter. I forbindelse med hans opvisninger, var der altid ved siden af det primære program med den primitive gymnastik, et program med idrætsgymnastik, som han kaldte det, hvis formål netop var, at vise, hvor langt gymnasterne var nået ${ }^{56}$.

I en beskrivelse af gymnastikhøjskolens første rejse med elevhold i 1922, beretter Kristian Krogshede om en opvisnings- og kulturaften i Wien, hvor de væsentligste ingredienser var opvisning, taler og dansk sang af østrigske børn, der havde været $\mathrm{i}$ pleje i Danmark under krigen. På sådan en aften, der var præget af skiftende total stilhed og bragende bifald, kunne man opleve, »hvordan legems $\emptyset$ velser kan være et middel til at skabe forståelse og venskab mellem mennesker af forskellig nationalitet, selv ikke sprogbarrieren kunne hindre det. Der er ingen tvivl om at vor rejse rundt $\mathrm{i}$ Østrig med opdragelsesmidlet gymnastik fik stor betydning $\ll^{57}$.

I optakten til en tur til U.S.A. i 1923 understreger Krogshede endnu engang sin opfattelse af gymnastikkens opdragende betydning, idet han understreger, at de rejste ud som repræsentanter for den danske ungdom, hvorfor de igennem nogle opvisninger ønskede at opnå en anerkendelse som sådan. Denne anerkendelse opnåede de til fulde gennem stor opbakning og imødekommenhed på turneen, hvilket gav holdet »en stærk følelse af ansvar over for opgaven $\aleph^{58}$. Den samme følelse fik også Bukh selv efter hjemkomsten fra U.S.A.: «Ved den lejlighed fik jeg impulser, som jeg aldrig vil glemme, så længe jeg lever. Fra den dag forstod jeg på en helt ny måde, at vi, når vi drager ud på vore ture, er repræsentanter for hele landet. Denne følelse har betydet meget for mig i mit arbejde. Den har gjort opgaverne større og rigere for mig, men den har også mangedoblet ansvaret, fordi jeg nu ved, at man hjemme i Danmark følger os med interesse og store forventninger. Gid vi aldrig må gøre den interesse $\mathrm{og}$ de forventninger til skamme $\ll^{59}$.

Der var mange, der mente at Bukh i stedet for at rejse verden rundt med sin gymnastik, hellere skulle koncentrere sin indsats på den danske ungdom hele året. Til det siger Kristian Krogshede, at man ikke må undervurdere betydningen af disse tures betydning for udbredelsen af den primitive gymnastik. »I U.S.A. var man blevet så optaget af dansk gymnastik, at der nu planlagdes særlige kurser for amerikanere. I Finland havde kaptajn Levälahti udtalt, at den primitive gymnastik nu havde vundet hævd i deres største ungdomsbevægelse Skyddskårene. I Tyskland var Niels Bukh's bog udkommet i 6 oplag, og primitiv gymnastik dyrkedes i alle egne af landet «. Han mener således, der var god grund til at man drog ud på »disse nutidens fredelige vikingetogter $\ll^{60}$.

Helt konkret fik Bukh syn for sagen, da han returnerede til U.S.A. i 1926, tre år efter han første gang havde præsenteret den primitive gymnastik i Guds eget land. På en skole i New York havde en tidligere kvindelig Ollerup-gymnast fået ansættelse, og det har sikkert frydet Bukh at komme over og se de kvindelige gymnasters hårde arbejde med den primitive gymnastik. Krogshede skriver følgende om oplevelsen: »Gymnastikken ved skolen var ganske forandret siden vi så den i 1923, da var den nærmest svensk, nu var det derimod grundgymnastik i ordets bedste betydning. Uden antydning af angst for, at disse unge piger skulle miste deres kvindelighed, lod Emily Andrews dem bøje og strække og vride sig $i$ et tempo og med en så djærv kraft, at var- 
me og humør på naturlig måde kom frem, men også sådan, at sikkert mange kvindelige gymnastikpædagoger i Danmark forarget-ville vende sig bort. De amerikanske pigers glade og ivrige ansigter borgede imidlertid for, at de befandt sig vel, og deres ranke, velformede og duelige legemer var et talende vidnesbyrd om arbejdets gode virkning. Det var en rigtig primitiv time med det rette tempo og en fart, så man som tilskuer måtte holde igen på sig selv for ikke at springe ud over balkonen for at arbejde med i rækkerne $\ll^{61}$.

Bukh var af den opfattelse, at gymnastikken kunne være et middel $i$ tilvejebringelse af en form for mellemfolkelig forståelse. Disse overvejelser gav han udtryk for efter de olympiske lege i Paris i 1924. Han havde da deltaget med et hold udenfor konkurrencen, hvilket var hans betingelse for at deltage. Han mente, at de hensynsløse begær efter førstepladser og nye rekorder betød, at de olympiske lege med konkurrenceidrætterne som det centrale stod overfor en snarlig afvikling. Som et alternativ til dette udtrykte han interesse for afholdelse af en gymnastikolympiade, »hvorfra al konkurrence skulle være udelukket, hvor hold fra hele verden samledes alene for at lære af hinanden og glædes over hinandens arbejde, så fællesskabets ånd kunne komme til at råde over denne ungdomsfest til gavn for udviklingen af forståelse og samarbejde mellem nationerne $\ll^{62}$.

Han var af den overbevisning at der i de unges bevidsthed kunne skabes og fremelskes en mellemfolkelig forståelse, som kunne kompensere for det had, som afstedkom fra forskellige krige og andre stridigheder. Denne ide fik han bestyrket ved eksempelvis at se japanere og kinesere i fredelig sameksistens på skolen, samtidig med at de to lande var i krig med hinanden. Rask Nielsen mener, at det var den samme overbevisning, der kun fik ham til at komme med nogle forsigtige udtalelser under besættelsen, som ikke på nogen måde klart og entydigt tog afstand fra herrefolkets overgreb. Rask Nielsen mener ikke, at Bukh ønskede at støde besættelsesmagten for meget, og dermed medvirke til at de forbindelser, der skulle genoptages efter krigen, blev yderligere vanskeliggjort. Samtidig ønskede han heller ikke at opdele sine mange venner og elever over hele jordkloden i venner og fjender ${ }^{63}$.

Om denne manglende afstandstagen skyldtes hans hensyn til venner, eller den skyldtes sympatien for det tyske, er det selv sagt svært at vide, men konsekvensen blev under alle omstændigheder, at det fra forskellig side blev tolket, som om han var pro-tysk, og afstedkom beskyldninger om at han var nazist, hvilket til sidst kulminerede med sigtelsen for kollaboratisme $\mathrm{i}$ retsopgøret efter krigen. En anklage, der dog på det pureste blev afvist, efter at hans forhold var blevet undersøgt.

Bukh så, som allerede nævnt gymnastikken, som et middel mod erhvervsarbejdets skadelige indvirkning på kroppen. Følgelig var gymnastiklederens opgave langt større end blot at formidle indlæringen af nogle bestemte gymnastiske discipliner, »thi den ligger $\mathrm{i}$ at lede arbejde for menneskers skyld, og først og fremmest skal arbejdet ledes ind over de felter, hvor vanrøgt og misbrug har sat sine spor « ${ }^{64}$. Det var altså afgørende at lederen havde det rette mål for $\varnothing j \mathrm{j}$, og hele tiden koncentrerede sit arbejde i retningen af dette definerede mål. Midlet, de gymnastiske $\varnothing$ velser, måtte derfor udtænkes og gennemføres med henblik på det erklærede mål, og ikke blot kopieres fra et etableret system, hvis der ikke var dokumentation for virkningen.

Det var vigtigt, at lederen virkelig troede 
på det nyttige i gymnastikken, som et »nødvendigt middel i folkeopdragelsens tjeneste $\ll$. Teoretisk viden alene gjorde ingen til en god leder, nok så vigtigt var det at have den rette indstilling, samt egne erfaringer med gymnastikkens virkning på kroppen ${ }^{65}$. Endvidere var det vigtigt, at lederen havde sans for »skønheden i menneskelegemet, sådan som denne kan ses hos harmonisk udviklede gymnaster eller fremtræder i den gode kunst $\ll^{66}$.

Bukh var af den opfattelse, at delingsførerne i deres uddannelse skulle have så meget praktisk gymnastik som muligt, da det »for at være en god leder af andres praktiske arbejde, også når det gjaldt om at få ungdommen til at dyrke egne forsømte legemlige evner og egenskaber, var selv at være en dygtig arbejder og selv have grundig erfaring $\mathrm{i}$ hele det praktiske arbejdes indgribende virkning og herlige lyst ${ }^{67}$. Bukh kritiserer i den forbindelse en række andre institutioner ${ }^{68}$, som han finder bevidst søger at holde undervisningen på det teoretiske plan, fordi det er det mest ansete, og samtidig det mest bekvemme for alle parter, »det er en utrolig agtpågivenhed autoriteterne viser overfor dette, at gymnastikken ikke skal blive for virksom, så den skulle skade de små kroppe. Mon der passes lige så godt på, at uforstående religionslærere f.eks. ikke gør de små sjæle fortræd, eller at skolen ikke overlæsser børnenes forstand? $\ll^{69}$.

I sin ledelse af Gymnastikhøjskolen forventede Bukh, at lærerstaben engagerede sig fuldt ud i arbejdet med eleverne, og brugte så mange ressourcer som det var muligt, på at pleje fællesskabet på skolen til alles bedste. »Det er udemærket, at I er dygtige til at undervise $\mathrm{i}$ dansk, regning, $\mathrm{i}$ svømning, idræt og gymnastik, men det er altsammen uden værdi, hvis I ikke interesserer jer for eleverne som mennesker, og har dem i jeres tanker også uden for timerne $\ll^{70}$. Dette var indholdet $\mathrm{i}$ en lille opsang, han en dag gav lærerstaben ved formiddagskaffen, hvor man naturligvis ofte diskuterede arbejdet på skolen.

En af de afgørende grunde til Bukh's gennemslagskraft, har ganske afgjort været dynamikken i gymnastikken. Hvor den traditionelle lingske gymnastik var præget af arbejde i stillinger på samme sted, prioriterede Bukh de rytmiske bevægelser, i form af armsving samt kropsbøjninger og - sving. Endvidere har det nok også haft en vis appel, at gymnastikken var meget intensiv, $\mathrm{i}$ det Bukh ville bruge tiden så effektivt som muligt, hvilket resulterede i lange serier uden pauser og i et meget højt tempo. Tidligere havde man brugt meget tid på at lade eleverne indtage nye stillinger, som ofte skulle ændres. Disse overgange fra stilling til stilling, der som sagt tidligere optog meget tid, blev hos Bukh introduceret allerede under en igangværende $\emptyset$ velse, hvilket dels var meget tidsbesparende og dels var afgørende for opretholdelsen af intensiteten $\mathrm{i}$ lektionerne ${ }^{71}$.

Blandt Bukh's pædagogiske principper var den månedlige anskuelsesundervisning, hvor der blev gjort status over de enkelte elevers niveau. Denne status lå til grund for en eventuel omplacering til et bedre eller ringere hold. $\mathrm{Kr}$. Krogshede mente ikke, det gjorde noget, at eleverne fik set kendsgerningerne i øjnene, selv om det somme tider »sved i sjælen på dem, der måtte rykke ned «, for de skulle jo ud til et arbejde, der både krævede personlig styrke og selvstændighed $\aleph^{72}$.

Bukh, der ellers på alle øvrige områder var kategorisk modstander af nogen som helst form for konkurrence, mente altså godt, at den officielle sammenligning og 
vurdering af elevernes formåen, kunne være motiverende i denne sammenhæng.

\section{Idealisten, gymnasten, lederen og den harmoniske legemsbygning}

Der er tre karakteristiske retninger indenfor den moderne legemskultur, som introduceredes og udvikledes i Danmark i det forrige århundrede. Disse retninger er alle opkaldt på baggrund af deres ophav, og kaldes følgelig, tysk, svensk og engelsk.

Den tyske »Turnen « tager primært sit udgangspunkt i træningen af armene, og er karakteriseret ved brugen af redskaberne barre og reck. Den engelske sport er karakteriseret ved at benarbejde er centralt, som eksempelvis i en række boldspil og løb. Den svenske gymnastik er i modsætning til de andre retninger præget af en langt mere alsidig udvikling af kroppen, og søger i det hele taget at udvikle en harmonisk legemsbygning ${ }^{73}$.

Det var netop den harmoniske legemsbygning med en rank holdning, fast muskelstyrke og smidighed, som Niels Bukh stræbte efter i sin gymnastik. Han tog udgangspunkt i den svenske gymnastik, men lod den samtidig reformere, da han ikke fandt den rationel nok. Dels udviklede han en form for bevægelsesgymnastik, hvor tempo og dynamik blev de centrale begreber, og dels udviklede han de passive udstrækningsøvelser, som oftest udførtes med makker. De sidstnæunte $\emptyset$ velser er senere blevet meget kritiserede p.g.a. den indebyggede risiko for beskadigelse af ligamenter og muskeltilhæftninger.

Det var hensigten med denne artikel, at bidrage med et mere nuanceret billede af mennesket Niels Bukh og hans gymnastik.
I den trykte litteraturs vurderinger af Niels Bukh har der været en tendens til meget unuancerede fremstillinger, med et stærkt præg af følelser og holdninger frem for saglighed.

Den første fase i undersøgelsen var en klarlæggelse af nogle af de idealer Niels Bukh stod for, samt en analyse af hvorledes disse idealer afspejledes i hans gymnastik.

Det blev med al tydelighed fremført, at Bukh var idealist. De idealer, han stræbte efter var orden, perfektionisme og nationalisme. Han mente, at midlet til opnåelse af disse idealer var en stærk leder. Dette så han gennemført i Tyskland, samtidig med at »ordenen « genoprettedes, hvorfor han flere gange fremhævede Hitler, som idealet. I gymnastikken gav det nationale sindelag sig udtryk i fanens meget centrale placering under opvisningerne, medens ordenen $\mathrm{i}$ gymnastikken opretholdtes med en meget autoritær ledelse, hvor han kun accepterede det absolutte perfekte. Målet med gymnastikken var en genoprettelse af bønderkarlenes nedslidte legemer. Han stræbte efter den gode ranke holdning, som udstrålede sundhed, harmoni, kraft og energi.

Dernæst blev der ud fra forskellige synsvinkler fokuseret på nogle anatomiske og fysiologiske aspekter af gymnastikken. Der blev taget udgangspunkt i Bukh's egen kritik af den lingske gymnastik, og argumentationen for udviklingen af denne fra stillingsgymnastik til bevægelsesgymnastik. Endelig blev der set på en række kritikeres syn på Bukh-gymnastikken, og det blev på den baggrund diskuteret, hvorledes denne kan påvirke legemet.

Bukh udviklede den primitive gymnastik på baggrund af de dårlige erfaringer, han havde haft med den lingske gymnastik. I princippet kunne han godt godtage linggymnastikken. Derimod kunne han ikke 
acceptere, at Lings arvtagere blot ukritisk anvendte $\varnothing$ velserne uden at have et klart mål for øje. Gymnastikken blev derved, efter Bukh's opfattelse, ineffektiv og irrationel. Den gymnastik, som Bukh introducerede i stedet, var ikke et nyt system, men blot en anden måde, at bruge Lings øvelser på. Han gjorde stillingsøvelserne til bevægelsesgymnastik, således at stillingerne $\mathrm{i}$ princippet blev gennemført i en kontinuerlig rækkefølge uden pause. Samtidig sørgede han for, at kommandoer blev givet undervejs, så man undgik pauser, og i det hele taget blev hans gymnastik karakteriseret af intensitet og tempo.

Dertil kom nyudviklingen af nogle parvise udspændingsøvelser. Det var $\emptyset$ velser, hvor gymnasterne på skift øvedede smidighed, medens makkeren på forskellig måde sørgede for absolut maximal udspænding, ved med hurtige rytmiske bevægelser at påvirke det pågældende led med sin kropsvægt. Dette blev skarpt kritiseret, da øvelserne kunne være direkte skadelige overfor ryggens ligamenter. Også på mange andre områder blev Bukh's gymnastik mødt af mere eller mindre saglig kritik.

Endelig blev der redegjort for en række af Bukh's principper, hvad angår den formidlingsmæssige side af gymnastikken. Dels blev Bukh's syn på lederrollen diskuteret, og dels blev der redegjort for en række af Bukh's pædagogiske principper, samt for hvorledes gymnastikken anvendtes som opdragelsesmiddel for ungdommen.

I Bukh's opvisninger var der altid foruden den primitive gymnastik en afdeling med idrætsgymnastik. Dette havde til hensigt, at vise gymnasternes aktuelle niveau.
Så selv om Bukh erklærede sig for modstander af al konkurrence, var der i denne opvisningsgymnastik, indbygget en form for konkurrence blandt eleverne. Det var under opvisningen, at deres indsats i det daglige arbejde blev evalueret.

Gymnastikken havde ved siden af dens fysiske genoptræning af de fors $\varnothing m$ te legemer desuden andre funktioner. Den lærte først og fremmest gymnasterne orden, perfektionisme og samarbejde. Desuden skulle gymnasterne virke som det gode eksempel, når de rejste rundt $i$ ind- og udland. Det var blomsten af Danmarks ungdom, Bukh rejste rundt med, og de rejste som repræsentanter og ambassadører for Kongeriget. Gymnastikken blev herved midlet til en mellemfolkelig forståelse, hvilket også kom til udtryk i de mange venskaber, som med rod i gymnastikken knyttedes på tværs af grænserne.

Gymnastiklederens rolle, var efter Bukh's mening langt større end blot at instruere i nogle $\emptyset$ velser. Lederfunktionen handlede om at omforme mennesker, og var som sådan nok så vigtig.

Bukh mente, at der for at være en god leder fordredes dels en oprigtig tro på arbejdets nyttevirkning, dels æstetisk forståelse, hvilket ville sige, at en præcis forestilling om, hvad der skulle stræbes efter, og endelig krævedes det at gymnastiklederen havde den nødvendige teoretiske baggrund, samt en praktisk erfaring der gjorde, at han havde mærket $\emptyset$ velsernes virkning på egen krop. Disse forhold var alle, efter Bukh's mening, nødvendige forudsætninger for at blive en god leder. 


\section{Noter}

1. Se bl.a. Rask Nielsen, Kristian Krogshede, Mads Nielsen, K.A.Knudsen etc.

2. Se bl.a. J.Lindhard, Ove Bøje og Axel Jensen

3. Se en nærmere karakteristerik af Bjørksténs gymnastik i G.Wichmann: Elli Bjørkstén (Helsingfors, 1965), Leena Laine: In search of a physical culture for Women -Elli Bjørkstén and women's gymnastics (i Scandinavian journal of sport sciences, oct. 1989, pp. 15-21) samt Ove Korsgård: Kampen om kroppen, pp. $226 \mathrm{f}$.

4. Ollerup folkehøjskoles årsskrift 1915. Tillige citeret i Rask Nielsen: Niels Bukh, p. 32

5. Citeret fra: Ove Korsgård: Kampen om kroppen, p. 229

6. Se Annali Rytter Christiansen og Marianne Hyllested: Fra Niels Bukh til Jane Fonda.....hvor de har foretaget en komparativ analyse af Niels Bukhs primitive gymnastik og Jane Fondas »Workout $«$. De mener generelt, at der er så mange slående lighedspunkter mellem de to gymnastikformer både hvad angår form og indhold, så de konkluderer, at der blot er tale om »ny vin på gamle flasker« tilsat nogle discorytmer «.

7. Mads Nielsen (tidligere elev og lærer på Ollerup, Forstander på Viborg Gymnastikhøjskole), Højskolebladet, 4.8.1950, citeret i Rask Nielsen: Niels Bukh, p. 204

8. Krogshede kommer med denne karakteristik i en TV-portræt-udsendelse fra Danmarks Radio om Bukh. Udsendelsen er formentlig optaget i slutningen af 1970'erne. Det har desværre ikke været muligt, at finde ud af præcis, hvornår udsendelsen er optaget.

9. Se bl.a Niels Bukhs brev til eleverne i Årsskrift for Gymnastikhøjskolen, 1924.

10. Citeret fra Kr. Krogshedes: Minder fra Ollerup,.p. 174

11. Kr. Krogshede beskriver i et TV-interview i 1982, hvorledes Bukhs elitehold var langt smidigere end svenskerne. »De svingede sig op fra vinkelsiddende til en flot, flot spændbøjning, men de fik ikke noget for det - for det var ikke lingsk. Det kunne ikke komme ind under systemet... ligeledes gik det, da han lavede en dyb, ensidig knæbøjning, hvor hele holdet gik ned med det ene ben strakt og så i en dyb knæbøjning med det andet - og så tillige med en fin armstilling - det flotteste man nogen sinde havde set, men av, - lingske gymnaster måtte kun bøje begge ben på en gang - og samtidig blev de underkendt fordi de sad i græsset - men hvis man var nogle centimeter over var det o.k.«. Denne tilsidesættelse af Bukhs nye stillinger sammenholdt med mødet med frk. Bjørkstén og de impulser hun bragte var afgørende for Bukh's nytænkning, mener Krogshede.

12. Rask Nielsen: Niels Bukh, p. 65-66

13. Udtalelserne var til dagbladet B.T., og er citeret i Rask Nielsen: Niels Bukh, p. 71

14. Rask Nielsen: Niels Bukh, p. 75

15. Se beskrivelsen af Sovjet-turen i Rask Nielsen: Niels Bukh, p. $116 \mathrm{f}$.

16. I en avisartikel fra $1933 \mathrm{kom}$ han bl.a. med følgende udtalelser: «Hvis jeg var 20 år yngre, ville jeg gerne tage den opgave op i Danmark, som Hitler havde løst i Tyskland, ...« (Berlingske Tidende 21.3.1933)

17. Berlingske Tidende. d.21.3.1933

18. Rask Nielsen: Niels Bukh, pp. 150-155

19. Årsskrift for Ollerup Gymnastikhøjskole, 1936, også citeret i Rask Nielsen: Niels Bükh, p. 170.

20. Rask Nielsen: Niels Bukh, pp. 225-227

21. Arne Mortensen kommer med udtalelserne i et T.V.-interview i 1982

22. Udtalelser fra en T.V.-portræt udsendelse om Niels Bukh udsendt af Danmarks Radio formentlig i slutningen af 1970'erne.

23. Niels Bukh: Gymnastik for den arbejdende ungdom, p. 16

24. Niels Bukhs brev til eleverne i Årsskrift for Ollerup Gymnastikhøjskole, 1930, p. 67

25. Niels Bukh: Primitiv grundgymnastik. 1970, p. 9 og i Årsskrift for Ollerup Gymnastikhøjskole, 1930, p. 67

26. Niels Bukh: Gymnastik for den arbejdende ungdom, pp. 8-9

27. Niels Bukh: Gymnastik for den arbejdende ungdom, p. 9 og i Årsskrift for Gymnastikhøjskolen, 1930, p. 69

28. Niels Bukh: Gymnastik for den arbejdende ungdom, p. 9

29. Niels Bukh: Primitiv grundgymnastik. 1970, p. 9

30. Bukh beskriver sine oplevelser af skolegymnastikstævnet i elevforeningens årsskrift, 1934. Han fik i øvrigt på baggrund af dette taget initiativ til at oprette årskurser for skolelærere på Gymnastikhøjskolen, så at også de kunne lære den »rigtige« gymnastik. Se bl.a. Rask Nielsen: Niels Bukh, pp 159-160

31. Bukhs brev til gamle elever i Årsskrift for Gymnastikhøjskolen 1930, p. 66 
32 Niels Bukh: Primitiv grundgymnastik. 1970, p. 10-11

33. Niels Bukh: Primitiv grundgymnastik. 1970, p. 12

34. Ove Korsgård: Kampen om kroppen, p. 232

35. Nogle af de skarpeste kritikere var Ove Bøje og J.Lindhard, begge læger, samt en række ansatte fra Statens Gymnastikinstitut, bl.a. lærer Ottar.

36. Han er dog stor modstander af, at nogle ledere ændrer dele af hans gymnastik ved at blande andre »ejendommelige foretagender ind $\mathrm{i}$ arbejdet $\ll$. Han ser her en fare $i$, at denne forvanskning af den primitive gymnastik, kan bevirke, at den mister noget af »sin friskhed og værdifulde virkning «. Der er altså, hvad angår børnegymnastikken ikke noget $\mathrm{i}$ vejen for en videreudvikling af gymnastikken, medens han helst ikke ser unødige fornyelser i voksen-gymnastikken. (Niels Bukh: Primitiv grundgymnastik. 1970 , p. 15 + p. 18)

37. Niels Bukh: Primitiv grundgymnastik. 1970, p. 145

38. Vedrørende alle disse af Bukh definerede holdningsfejl, se i øvrigt bl.a. Niels Bukh: Primitiv grundgymnastik. 1970, p. 31-34, samt Niels Bukh: Gymnastik for den arbejdende ungdom pp. 11 f.). Nedenstående er enkelte af holdningsfejlene forklaret. Undertegnede har tilføjet de latinske navne, hvor det fandtes nødvendigt.

Buehals er forårsaget af hovedets konstante tryk, der virker til forøgelse af halsens krumning. Da den lange halsmuskel (m.sternocleidiomastoideus) ikke trænes i hverdagen opstår fejlen.

På samme måde virker skuldre og arme med et tryk på hvirvelsøjlen (columna vertebralis), som derved får et tryk bagud i brystdelen (pars thoracalis). Dette er muligt da de lange rygstrækkere (m.erector spinae) heller ikke trænes i hverdagen. Herved opstår den holdningsfejl, som Bukh kalder rundryg.

Svejryg opstår som en konsekvens af en forøget bækkenhældning, som skyldes hele overkroppens tryk på lænden. Denne fejl opstår lettere, hvis forsidemusklerne (m.rectus abdominis, m. obliquus abdominis externus, m.obliquus abdominis internus) er svage. Der kompenseres dog naturligt for en for voldsom hældning ved at hasemusklerne (hamstrings-gruppen, d.v.s. m.bicebs femoris, m.semitendinosus og m.semimembranosus) trækker bækkenhældningen i modsat retning. M.h.t. de øvrige holdningsfejl er der igen tale om muskelgrupper, der enten er for svage, for korte eller for lange.

39. De unaturlige krumninger vil specielt give problemer med bevægelser $\mathrm{i}$ retning af krumningernes konveksiteter, og samtidig vil muskelgrupper, der spænder over en konveksitet blive for lang, og samtidig for svag, idet det ikke er muligt på optimal måde at træne en muskels koncentriske kraft, hvis den spænder over et mindre fleksibelt område. Omvendt vil de tilsvarende antagonister på den konkave side af krumningen blive relativt for stærke. (se bl.a. Bukhs forklaringer af disse forhold i Niels Bukh: Gymnastik for den arbejdende ungdom, p. 12)

Risikoen for deformering af leddene har ganske afgjort været større på Bukhs tid end i dag. Dette skyldes ikke alene de hårdere fysiske krav, og et ensidigt arbejde, men også den tids kostsammensætning kan have haft betydning. Den ofte meget ensidige kost har næppe altid indeholdt tilstrækkeligt calcium, og derved har leddene, udsat for den forkerte belastning, haft sværere ved at modstå deformering.

40. De strækkemuskler, som Bukh fortrinsvis peger på er armstrækkerne (m.triceps bracchi), hofteleddets strækkere (primært m.gluteus maximus), knæstrækkerne (m.quadriceps femoris) samt fodleddets strækkere (m.gastrocnemius og m.soleus) Se bl.a. Niels Bukh: Gymnastik for den arbejdende ungdom, p. 15

41. D.v.s. hamstringsgruppen (m. biceps femoris, m.semimen-branosus, m.semitendinosus)

42. Se bl.a. Rask Nielsen: Niels Bukh, pp 34-35

43. Kristian Krogshede: Minder fra Ollerup og Gerlev, p. 61

44. Niels Bukh: Gymnastik for den arbejdende ungdom, p. 9-10

45. Niels Bukh: Gymnastik for den arbejdende ungdom, p. 10

46. J.Lindhard: Den specielle gymnastikteori, pp. 4549

47. ibid.

48. ibid.

49. J.Lindhard: Den specielle gymnastikteori, p. 48

50. Vedrørende Bøjes synspunkter, se bl.a. hans artikel i Jyllandsposten 28.8.1969, »Smidiggørende gymnastik....

51. De væentligste ligamenter (ledbånd) omkring hvirvelsøjlen er dels ligamentum longitudinale anterius, som løber langs hvirvels øjlens forside, og i lighed med torntappenes fremspring er med til at sikre mod for store bagudbøjninger. Fremadbøjninger hindres primært af ligamentum longitudinale posterius, der løber langs hvirvelsøjlens bagside (d.v.s. på bagsiden af corpus vertebra, hvirvellegemet, $\mathrm{i}$ forreste del af hvirvelhullet (for- 
amen vertebrale)), samt af kroppens eneste elastiske ligament ligamentum flava, som løber mellem hvert af leddene i den bagerste del af hvirvelhullet.

52. Ove Bøje: Smidiggørende gymnastik...

53. Der kan være flere årsager til rygsmerter. Når Bøje taler om ischias er der tale om en typisk overbelastningsskade af hvirvelsøjlen, som kan skyldes de meget kraftige (og specielt de passive) udspændinger. Skaden og dermed smerten opstår ved, at der sker en brist på discus’ fibrøse del (anulus fibrosus), hvorved dele af den bløde masse i discus' centrale del (nucleus pulposus) presses ud. Når dele af nucleus pulposus presser på ligamentet opstår smertefølelsen via receptorer i disse. Denne smerte ophører dog, såfremt man ikke længere overbelaster leddet. Derimod kan skaden blive værre og mere smertefuld, såfremt nucleus pulposus presses så langt ud i hvirvelrummet (foramen vertebrale), at den begynder at trykke på de nerver, som passerer igennem. Man kan da opleve at få ischias, som er smerter i benene, forårsaget af de nervetråde (ischiasnerven), som har forbindelse til muskelgrupper i benene.

Det skal dog understreges, at der undertegnede bekendt, ikke er nogen videnskabelig dokumentation for den af Bøje antydede sammenhæng mellem gymnastik og diskusprolaps.

54. Citeret fra Ernst Møller: Niels Bukh -og skolegymnastikken, p. 109-110

55. Niels Bukh: Gymnastik for den arbejdende ungdom, p. 9

56. Niels Bukh: Primitiv grundgymnastik. 1970, p. 17

57. Kristian Krogshede: Minder fra Ollerup og Ger- lev, p. 72

58. Kristian Krogshede: Minder fra Ollerup og Gerlev, p. 87

59. Artikel i dagbladet B.T., citeret i Rask Nielsen: Niels Bukh, pp. 71-72

60. Kristian Krogshede: Minder fra Ollerup og Gerlev, p. 122

61. Kristian Krogshede: Minder fra Ollerup og Gerlev, p. $128 \mathrm{ff}$

62. Citeret fra Rask Nielsen: Niels Bukh, p. 74

63. Se Rask Nielsen: Niels Bukh, p. $219 \mathrm{f}$.

64. Niels Bukh: Primitiv grundgymnastik. 1970, p. 13

65. Niels Bukh: Primitiv grundgymnastik. 1970, p 18-19

66. Niels Bukh: Primitiv grundgymnastik. 1970, p. 34

67. Niels Bukhs brev til eleverne 1926 i Årsskrift for Gymnastikhøjskolen, også gengivet i Kr. Krogshede: Minder fra Ollerup og Gerlev, p. 141

68. Han er i denne forbindelse generelt ude efter de fleste seminarier og specielt efter Statens Gymnastikinstitut, det senere Danmarks Højskole for Legems $\emptyset$ velser (se Niels Bukhs brev til eleverne 1926, gengivet i Krogshede: Minder, p. 141)

69. Niels Bukhs brev til eleverne i Gymnastikhøjskolens Årsskrift 1926, p. 120, samt gengivet i Kr. Krogshede: Ollerup og Gerlev, p. 141

70. Citatet fra Niels Bukh er at finde i Rask Nielsen: Niels Bukh, p. 196

71. A.H. Riiskjær: Gymnastikkens historie i hovedtræk, p. 59

72. Kristian Krogshede: Minder fra Ollerup og Gerlev, p. 61

73. Se bl.a. Ove Korsgård, p. $81 \mathrm{ff}$ og A.H. Riiskjær, p. 59

\section{Litteratur}

Nærværende litteraturliste er en oversigt over de hjælpekilder (bibliografier), bøger og artikler, som i mere eller mindre omfang ligger til grund for undersøgelsen. Det skal understreges, at listen på ingen måder gør krav på at være fuldstændig, hvad angår litteratur om Bukh. I særlig grad, hvad angår avisartikler, er disse kun medtaget i meget sporadisk omfang.
Monografier og artikler:

Aabye, Edgar: Niels Bukh og hans gymnastik (i Illustreret Tidende, 1922, årg.64, pp 168-169

Andersen, Frode: Neurofysiologiske synspunkter på gymnastiske $\emptyset$ velser (i Tidsskrift for Legemsøvelser, 1955, årg. 20, pp. 105-14)

Bukdahl, J. og Jensen, J. Marinus (red.): Fri ungdom 
(Odense 1944). (bl.a. med artikel af K.A.Knudsen: Gymnastikkens udvikling i Danmark)

Bukh, Niels: Gymnastik for den arbejdende ungdom (i Krogshede, K. m.fl.: Idræt - vor tids folkeopdrager)

Bukh, Niels: Primitiv Grundgymnastik (Sjette udgave, Odense 1970)

Bukh, Niels: Seriegymnastik (i Gymnastisk tidsskrift, 1918, pp. 14-16)

Bøje, Ove: Smidiggørende gymnastik kan fremkalde ryglidelser, artikel i Jyllandsposten 28.8.69

Christiansen, Preben (udg.): De danske, skytte-, gymnastik- og idrætsforeninger 1861-1971 (1971)

Clausen, Eliza F.: Debat (i Dansk ungdom og idræt, årg.91, nr. 19,1988, p. 11)

Danmarks folkehøjskoler 1844-1944 (Kbh. 1944)

Damkjær; Søren: Den levende handling - Niels Bukh (I Idrætshistorisk Årbog 1989, pp 67-75)

Diem, Carl: Die dänen I.p. Müller und Niels Bukh (i Olympische flamme bd.2, Berlin 1942, pp. 749754)

Engelbrecht, John: Vil du tænde, må du brænde. Fra delingsfører til gymnastikinstruktør. (1989)

Flensted Jensen, Erik: Med Niels Bukh jorden rundt (1932)

Gottlieb, J.C.: Niels Bukhs sidste opvisning (i Idrætten, 1917, årg.13, pp 329-331)

Hellerup, Niels: Nyt om gymnastikkens historie i Danmark (i Tidsskrift for Legems $\varnothing$ velser, 1968, Årg. 33, pp1-12)

Hemmingsen, Chr.: Den bukhske gymnastik (i militært tidsskrift, 1925, årg. 54, pp. 305-311)

Hemmingsen, Chr.: Et militært foredrag om den bukhske gymnastik (i Officiantbladet, 1925, årg. 25 , nr. 23

Hyllested, Marianne: se Rytter-Christiansen

Jacobi, W.: Undersøgelser på Ollerup Delingsførerskole vinteren 1917-18 (i Gymnastisk Tidsskrift, 1918, pp 171-177)

Jensen, Axel: Debatten som konfliktløsning (i Dansk ungdom og idræt, årg. 91, nr. 16, 1988, pp. 10-11)

Jerrild, Holger: Dansk gymnastik - en verdensartikel (i Dansk arbejde, 1937, årg.28, nr 21, pp 3-4, 16-19)

Joch, W: Sport und Leibeserziehung im dritten Reich (i Ueberhorst: Geschichte der Leibesübungen, 1982, bd. 3.2, pp. 701-743)

Kjærsgård, Magne: Niels Bukhs primitive gymnastik (i Højskolebladet, 1924, pp. 995-1000)

Korsgård, Ove: Kampen om kroppen (Gyldendal 1986)

Knudsen, K.A.: Niels Bukh og hans gymnastik (i Danmarksposten, årg.3, 1922, 155-157)
Knudsen, K.A.: Niels Bukh (artikel i Journal of health and physical education, 1939, vol 10, no.1.)

Krogshede, K: Minder fra Ollerup og Gerlev (1980)

Krüger, A: Die olympische Spiele 1936 und die Weltmeinung (Berlin 1972)

Lambertsen, M: Niels Bukhs gymnastikundervisning (i gymnastisk tidsskrift, 1917, pp. 74-78)

Lindhard, J.: Den specielle idrætsteori (Kbh. 1925)

Lindhard, J: Hr. Bukh's opvisning i Koncertpalæet 1.april 1917; (i A. Bertram m.fl.: Akademisk Gymnastik s. 47 (Kbh. 1919))

Lyngsgård, Hans: Idrættens rum (Borgen 1990)

Mehl, Erwin: Ein dänisches Dreigestirm erloschen. J. Lindhard - K.A.Knudsen - Niels Bukh (i Leibesübungen - Sportarzt - Erziehung 1, 1950, h.5, pp. 123-128)

Mehl, Erwin: Zum tode Niels Bukhs (i Leibesübungen - Sportsarzt - Erziehung 1, 1950, h.8, side 186187)

Møller, Ernst: Niels Bukh - og skolegymnastikken (i Tidsskrift for Idræt, årg. 45, nr. 3, 1980, pp. 107 111)

Nielsen, Mads: Dansk Gymnastik (Glamsbjerg 1971)

Nielsen, Mads: Niels Bukh 15.juni 1880- 7.juli 1950 (i Dansk ungdom og idræt, årg. 83, nr. 24, pp 415420, 1980)

Nielsen, Rask: Niels Bukh (1950)

Nielsen, Rask: Gymnastikhøjskolen i Ollerup (i Hermann, Aage og Andersen, Ewald (red.) Den danske idrætsbog, 1935, pp. 528-39)

Ollerup Gymnastikhøjskoles Årsskrift (1920-1950)

Ottar, O.A.: Niels Bukh og drengegymnastikken (i Tidsskrift for Legems $\emptyset$ velser, 1951, årg. 16, p. 2o ff.)

Primitiv Tidende. Gymnastikhøjskolen i Ollerup 1921/22-24

Ram-bukhen. Avis for Ollerup Gymnastikhøjskole vinteren 1929-30

Riiskjær, A.H.: Gymnastikkens historie (1942)

Rytter-Christiansen, Anna-Li \& Hyllested, Marianne: Fra Niels Bukh til Jane Fonda (i Focus Idræt, årg. 10, nr. 1, 1985, pp. 15-20

Rørdam, Johs.: Gymnastikhøjskolen i Ollerup (i Gymnastikhistorisk tidsskrift, 1920, pp. 81-89)

Skovrup, Einar: Niels Bukh og hans gymnastik (i Nær og fjern, 1923, årg. 1, pp 95-112)

Stamm, Hans: K.A.Knudsen und Niels Bukh (i Leibesübungen und Leibeserziehung 4, 1950, h.10/11, pp. 12-15

Thomsen, Else: Passive øvelser med hjælper (i Gymnastisk Tidsskrift, 1918, pp 39-41)

Trangbæk, Else: Mellem leg og disciplin (1987) 
Vaaben, Valdemar: Ollerup Gymnastikhøjskole, (i Højskolebladet, 1920, pp. 1207-1212

Diverse фvrige avisartikler:

Berlingske -Tidende: $2.4 .1917 \quad 3.9 .1917 \quad 6.9 .1917$ 21.3.1933 9.6.1940

Fyens Stiftstidende: 12.4. 1942 19.4. 1942

Fyns Tidende: 9.6.1940 29.10.1944

Holstebro Dagblad: 13.6.1940
Horsens folkeblad 14.6.1940

Hovedstaden: 3.8.1913

Idrætsliv: okt. 1917

National Tidende: 14.6.1940

Politiken: 6.9.1917 26.1.1919 28.12.1968

Ribe Amts Folkeblad 10.11. 1954

Ungdom og Idræt 23.3.1928

Vore Herrer: 20.9.1917 
-. 